Original Research Paper

\title{
Durian variety (Durio zibethinus L.) in Kota Bahagia District, South Aceh, Indonesia
}

\author{
Mardudi $^{*}$, Eka Selviyanti ${ }^{1}$, Adi Bejo Suwardi ${ }^{1}$ \\ ${ }^{1}$ Program Studi Pendidikan Biologi, FKIP Universitas Samudra, Kota Langsa, Provinsi Aceh, Indonesia
}

\section{Article History}

Received : December $30^{\text {th }}, 2020$

Revised : January $07^{\text {th }}, 2021$

Accepted : January $16^{\text {th }}, 2021$

Published : January $19^{\text {th }}, 2021$

*Corresponding Author:

Mardudi,

Program Studi Pendidikan

Biologi, Fakultas Keguruan dan

Ilmu Pendidikan, Universitas

Samudra, Meurandeh, kota

Langsa, Provinsi Aceh, Indonesia

Email: mardudajk@gmail.com

\begin{abstract}
Durian (Durio zibethinus L.) is one of tropical fruit grown in Southeast Asia and known as King of the fruit. Durian (D. zibethinus) has many varieties with distinctive of morphological characters. The study aim is to explore the diversity of durian varieties in Kota Bahagia sub-district, Aceh, Indonesia. This study was carried out in October-December 2020 in five villages, namely Jambo Keupok, Alur Duamas, Seneubok Alur Buloh, Seneubok Keranji and Beutong. Data collection on the morphological characteristics of durian varieties was carried out through direct field observation of morphology. The data were tabulated and the similarity index was calculated. A total of 18 varieties of durian were found in 5 villages in Kota Bahagia sub-district, i.e. Jantung, Semut, Nanas, Kunyit, Bintang, Tamago, Labu, Bingen, Patai, Jelatang, Jerat, Ampo, Toba, Lilin, Kondo, Limeng, Langsat, dan Gadang Tampok. The highest similarity index value was found in Limeng $(\mathrm{Lm})$ and Patai $(\mathrm{Pa})$ varieties with an association coefficient value of 63.04, while the lowest values were found in Nanas (Na) and Semut (Se) varieties and Kondo (Ko) and Nanas (Na) varieties with an association coefficient of 15.21 .
\end{abstract}

Keywords: Durian; Morphology; Prospect; Kota Bahagia

\section{Pendahuluan}

Provinsi Aceh yang merupakan salah satu daerah yang diketahui memiliki keanekaragaman jenis tumbuhan buah lokal yang tinggi (Navia et al., 2019; Suwardi et al., 2019a; Navia et al., 2020; Suwardi et al., 2020a). Buah-buahan tersebut ada yang telah dibudidayakan (Elfrida et al., 2020; Navia et al., 2017; Suwardi et al., 2019b; Novarian et al., 2020; Sembiring et al., 2020; Navia et al., 2021) dan ada yang ditemukan tumbuh liar (Navia et al., 2020b; Suwardi et al., 2020b).

Durian (Durio zibenthinus L.) merupakan salah satu jenis tanaman buah tropis yang dikenal sebagai The King of Fruit (Feng et al., 2016). Durian diketahui sebagai tumbuhan asli Indonesia (Uji, 2005). Ada sekitar 31 jenis durian di seluruh dunia, 19 jenis diantaranya ditemukan di Kalimantan dan 7 jenis durian lainnya tersebar di Sumatera dan sebagian besar masih tumbuh liar di hutan (Uji, 2005; Mansur et al., 2007; Navia dan Tjikmawati, 2015).
Durian (D. zibethinus) merupakan salah satu jenis buah yang popular di Indonesia, memiliki rasa dan aroma yang khas serta digemari oleh banyak orang (Najira et al., 2020). Rasa buahnya yang manis dan aromanya harum menjadi daya tarik tersendiri bagi pencinta durian, mulai dari anak-anak hingga orang dewasa. Warna daging buahnya beragam, dari warna putih, kuning, hingga oranye. Bagian buah durian yang umum dikonsumsi adalah bagian salut buah atau dagingnya. Buah durian memberikan manfaat bagi manusia, diantaranya sebagai makanan, olahan, perawatan kecantikan, anti kanker, meningkatkan tekanan darah dan sebagai afrodisiak (Purnomosidhi et al., 2002; Rusmiati et al., 2013).

Kecamatan Kota Bahagia memiliki iklim yang mendukung bagi pertumbuhan tumbuhan durian. Berbagai jenis buah durian yang dihasilkan ternyata memiliki keanekaragaman sifat morfologi, maupun kualitas buahnya (Handayani et al., 2017). Sebagian besar masyarakat hanya mengetahui beberapa jenis buah durian saja, seperti durian monthong dan musang king. Berbeda dengan durian 
lokal lainnya yang ada di Indonesia, pemberian nama pada buah durian yang ada di Aceh Selatan tepatnya di Kecamatan Kota Bahagia didasarkan pada apa yang di lihat. Sebagai contoh, durian dengan ciri khas pada bagian duri buah nya selalu di kerumuni oleh kawanan semut, maka disebut dengan durian semut. Karakterisasi morfologi genotipe tanaman durian (D. zibethinus) diharapkan dapat mengungkapkan potensi keunggulan tanaman durian yang dapat digunakan sebagai acuan untuk mengenalkan jenis-jenis durian yang ada di Kecamatan Kota Bahagia sebagai salah satu kawasan kawasan Taman Nasional Gunung Lauser yang berada di Aceh Selatan, untuk ruang lingkup yang lebih luas (Nurlaila et al., 2019).

Kurangnya pengetahuan serta informasi mengenai durian asal Aceh bagian selatan ini menyebabkan lemahnya perlindungan serta pelestarian terhadap kekayaan alam. Selain itu, introduksi bibit durian impor menyebabkan varietas durian lokal kalah bersaing dan dalam jangka panjang dapat megkibatkan kepunahan (Salasa et al.,2013). Penelitian ini bertujuan untuk mengeksplorasi keanekaragaman varietas tanaman buah durian yang ada di Kec. Kota Bahagia, Aceh, Indonesia. Penelitian ini dilakukan sebagai upaya memperkenalkan serta mengembangkan potensi varietas durian yang ada di Kec.Kota Bahagia.

\section{Bahan dan Metode}

\section{Tempat penelitian}

Penelitan dilaksanakan pada bulan Oktober - Desember 2020. Lokasi pengambilan sempel dilakukan di 5 desa di Kecamatan Kota Bahagia, yaitu Jambo Keupok, Alur Duamas, Seneubok Alur Buloh, Seneubok Keranji dan Beutong.

\section{Bahan dan Alat}

Alat yang diperlukan seperti kamera, panduan deskripsi tanaman durian, dan alat-alat tulis. Bahan yang diperlukan dalam penelitian ini adalah tanaman durian yang terdapat di lima desa yang ada di Kec. Kota Bahagia.

\section{Pengumpulan Data}

Pengumpulan data ciri morfologi dari varietas durian dilakukan dengan cara pengamatan morfologi secara langsung dilapangan yang mengacu pada buku Descriptor for Durian (Durio zibethinus Murr.) (Biodiversity International, 2007). Data yang diamati meliputi karakteristik batang, daun, dan buah.

\section{Analisis Data}

Analisis data dilakukan dengan statistik deskriptif. Indeks kesamaan dari tiap pasangan Satuan Taksonomi Operasional (STO) dihitung dengan menggunakan rumus koefisien asosiasi (Sundari, 2014):

dimana,

$$
S=\frac{N s}{N s+N d} \times 100
$$

$\mathrm{S}=$ koefisien asosiasi sepasang STO yang dibandingkan

Ns = jumlah karakter yang sama (1) untuk sepasang STO

Yang dibandingkan

$\mathrm{Nd}=$ jumlah karakter yang tidak sama (0) pada satu STO

dan pada STO yang lain untuk sepasang STO yang dibandingkan

\section{Hasil dan Pembahasan}

\section{Keragaman morfologi tanaman durian di Kec. Kota Bahagia, Kab. Aceh Selatan}

Kecamatan Kota Bahagia merupakan nama desa yang berada di Kabupaten Aceh Selatan yang memiliki luas wilayah $24.463,29$ ha dengan jumlah penduduk mencapai 7,226 jiwa dengan rata-rata pertumbuhan penduduk sebesar $00,3 \%$. Sebagian besar masyarakat bermatapencaharian sebagai petani. Wilayah ini berada dikawasan Taman Nasional Gunung Leuser, yang memiliki Intensitas terkana sinar matahari langsung berkisaran $40-50 \%$ dengan suhu berkisar $26-30^{\circ} \mathrm{C}$ yang sesuai dengan kondisi pertumbuhan tanaman durian. Curah hujan di Kec. Kota Bahagia mencapai $3.185 \mathrm{~mm}$ per tahun. Letak geografis Kec. Kota Bahagia sendiri mencapat ketinggian 50-1000 meter diatas permukaan laut, dengan kemiringan lereng $0 \%$ - >40\% (BPS, 2019).

Persebaran Varietas Durian (D. zibethinus L.) di Kec. Kota Bahagia, Kab. Aceh Selatan.

Sebanyak 18 varietas durian ditemukan di 5 desa di Kec. Kota Bahagia, Kab. Aceh Selatan. Varietas tersebut antara lain Jantung, Semut, Nanas, Kunyit, Bintang, Tamago, Labu, Bingen, Patai, 
Jelatang, Jerat, Ampo, Toba, Lilin, Kondo, Limeng, Langsat, dan Gadang Tampok (Tabel 1).

\section{Keanekaragaman Morfologi Durian (Durio zibethinus L.) di Kec. Kota Bahagia}

Berdasarkan hasil dari pengamatan karakter dan morfologi genotipe pada durian yang berada di Kec. Kota Bahagia, Kab. Aceh Selatan menunjukkan adanya keragaman pada ciri morfologi batang, daun dan juga buah (Tabel 2, 3, dan 4). Hasil pengamatan terhadap 47 karakter yang didasarkan pada persamaan STO yang merupakan hasil pemisahan jumlah karakter sama yang dibandingkan (1) dan dengan jumlah karakter beda (0) yang dibandingkan ditunjukkan pada Tabel 5.

Nilai indeks kesamaan tertinggi terdapat pada varietas Limeng $(\mathrm{Lm})$ dan varietas Patai $(\mathrm{Pa})$ dengan nilai koefisien asosiasi sebesar 63,04, sedangkan nilai terendah terdapat pada varietas Nanas (Na) dengan varietas semut (Se) dan varietas Kondo (Ko) dan varietas Nanas $(\mathrm{Na})$ dengan nilai koefisien asosiasi masing-masing sebesar 15,21. Nilai indeks kesamaan sebesar 63,04 atau mendekati 100 menunjukkan tingkat kesamaan yang tinggi. Tingkat perbedaan dan persamaan ditentukan oleh jumlah karakter sama dan berbeda yang dipengaruhi oleh interaksi antara faktor genetik dan lingkungan. Menurut Hardiyanto et al., (2006) bahwa varietas lokal memiliki variasi sifat morfologi yang yang dipengaruhi oleh faktor ekologi dan geografi dari populasi. Selanjutnya, Yuniarti (2011) menyatakan bahwa persamaan karakter morfologi dipengaruhi oleh faktor lingkungan dan genetik, dimana karakter yang muncul karena pengaruh dari lingkungan tidak dapat diwariskan pada keturunan berikutnya apabila memiliki kondisi geografis yang berbeda.

\section{Prospek pengembangan durian di Kec. Kota Bahagia}

Produksi durian di Kec. Kota Bahagia tergolong tinggi dengan kuantitas panen durian per musim mencapai 568 kwintal (BPS, 2018). Pemasaran buah durian telah dilakukan pada berbagai daerah seperti Medan, Subulussalam, Meulaboh, dan Banda Aceh bahkan Surabaya dan Bandung. Kegemaran masyarakat dalam mengkonsumsi buah durian menjadi salah satu faktor pendukung pengembangan durian di Kec.Kota Bahagia. Berdasarkan hasil wawancara dengan responden diketahui bahwa varietas durian Jantung, durian Kunyit, dan durian Labu merupakan varietas unggulan masyarakat dan paling digemari dikarenakan kualitas rasa dan keindahan bentuk buahnya. Budidaya durian menjadi bisnis yang prospektif, selain buahnya yang enak, masa panen durian juga relatif singkat ( \pm 3 tahun) sehingga menjadi komoditas yang potensial untuk dikembangkan (Santoso, 2014). Meskipun demikian, pengetahuan budidaya durian masih terbatas dikalangan masyarakat Kec. Kota Bahagia. Hal ini menyebabkan tanaman durian baru sebatas dijadikan sebagai usaha sampingan. Belum ada masyarakat atau kelompok masyarakat yang melakukan usaha budidaya durian secara intensif. Budidaya tumbuhan buah lokal termasuk durian dapat meningkatkan pendapatan masyarakat yang tinggal di daerah pedesaan (Purba et al., 2020; Suwardi et al., 2020c).

Tabel 1. Persebaran varietas durian pada 5 desa di Kec. Kota Bahagia

\begin{tabular}{cll}
\hline No & Varietas & Lokasi ditemukan \\
\hline 1 & Jantung & Jambo Keupok, Alur Dua mas, Seneubok Alur Buloh, Seneubok Keranji \\
2 & Semut & Jambo Keupok, Alur Duamas \\
3 & Nanas & Jambo Keupok, Alur Duamas, dan Seneubok Alur Buloh \\
4 & Kunyit & Jambo Keupok, Alur Duamas, Seneubok Alur Buloh, Seneubok Keranji \\
5 & Bintang & Jambo Keupok, Alur Duamas, dan SeneubokAlurBuloh, Beutong \\
6 & Tamago & Jambo Keupok, Alur Duamas, dan Seneubok Kranji \\
7 & Labu & Jambo Keupok, Alur Duamas, Beutong, Seneubok Buloh \\
8 & Bingen & Jambo Keupok, Alur Duamas, Seneubok Kranji, Seneubok Alur Buloh \\
9 & Patai & Jambo keupok, Alur Duamas \\
10 & Jelatang & Jambo Keupok, Alur Duamas \\
11 & Jerat & Jambo Keupok, Seneubok Alur Buloh, Seneubok Kranji \\
12 & Ampo & Jambo Keupok, Alur Duamas \\
13 & Toba & Jambo Keupok, Alur Duamas \\
14 & Lilin & Alur Duamas, Beutong, Senebok Keranji, Seneubok Buloh
\end{tabular}


Mardudi, et al. (2021). Jurnal Biologi Tropis, 21 (1): 42 - 51

DOI: http://dx.doi.org/10.29303/jbt.v21i1.2361

\begin{tabular}{lll}
15 & Kondo & Jambo Keupok \\
16 & Limeng & JamboKeupok, Alur Duamas, Seneubok Alur Buloh, Beutong \\
17 & Langsat & Jambo Keupok, Seneubok Kranji, Seneubok Alur Buloh \\
18 & Gadang Tampok & Jambo Keupok, Alur Duamas \\
\hline
\end{tabular}


Mardudi, et al. (2021). Jurnal Biologi Tropis, 21 (1): $42-51$

Tabel 2. Karakteristik morfologi pohon dari 18 varietasdurian di kecamatan kota Bahagia

\begin{tabular}{|c|c|c|c|c|c|c|c|c|c|c|c|c|c|c|c|c|c|c|}
\hline \multirow[b]{2}{*}{ Karakter } & \multicolumn{18}{|c|}{ Varietas } \\
\hline & Jantung & Semut & Nanas & Kunyit & Bintang & Tamago & Labu & Bingen & Patai & Jelatang & Jerat & Ampo & Toba & Lilin & Kondo & Limeng & Langsat & $\begin{array}{l}\text { Gadang } \\
\text { tampuok }\end{array}$ \\
\hline $\begin{array}{l}\text { Tinggi } \\
\text { Pogon }(m)\end{array}$ & 30 & 25 & 25 & 22 & 20 & 30 & 25 & 18 & 22 & 20 & 20 & 32 & 28 & 25 & 20 & 18 & 30 & 35 \\
\hline $\begin{array}{l}\text { Tinggi pohon bebas cabang } \\
\text { (m) }\end{array}$ & 25 & 20 & 24 & 20 & 16 & 26 & 22 & 15 & 22 & 22 & 17 & 29 & 26 & 233 & 17 & 15 & 25 & 31 \\
\hline Lingkar batang $(\mathrm{cm})$ & 120 & 110 & 110 & 120 & 80 & 105 & 80 & 65 & 80 & 80 & 75 & 120 & 75 & 90 & 70 & 70 & 90 & 125 \\
\hline Permukaan batang & Kasar & Kasar & Kasar & Kasar & Kasar & Kasar & Kasar & Kasar & Kasar & Kasar & Kasar & Kasar & Kasar & Kasar & Kasar & Kasar & Kasar & Kasar \\
\hline Pertumbuhan cabang & Beraturan & Rapat & $\begin{array}{l}\text { Tidak } \\
\text { beraturan }\end{array}$ & Beraturan & $\begin{array}{l}\text { Tidak } \\
\text { beraturan }\end{array}$ & Rapat & $\begin{array}{l}\text { Tidak } \\
\text { beraturan }\end{array}$ & Beraturan & Beraturan & $\begin{array}{l}\text { Tidak } \\
\text { beraturan }\end{array}$ & $\begin{array}{l}\text { Tidak } \\
\text { beraturan }\end{array}$ & Rapat & Rapat & $\begin{array}{l}\text { Tidak } \\
\text { beraturan }\end{array}$ & Beraturan & $\begin{array}{l}\text { Tidak } \\
\text { beraturan }\end{array}$ & Rapat & Rapat \\
\hline Diameter tajuk (m) & 26 & 23 & & 18 & 15 & 25 & 22 & 15 & 20 & & 18 & 24 & 22 & & 19 & & 25 & 32 \\
\hline $\begin{array}{l}\text { Bentuk tajuk } \\
\text { Ba }\end{array}$ & Jorong & Jorong & Lonjong & Bulat & Bulat & Lonjong & Membulat & Lonjong & Lonjong & Lonjong & Bulat & Lonjong & Lonjong & Bulat & Bulat & Lonjong & Lonjong & Membulat \\
\hline Pertumbuhan pohon & Keatas & Keatas & Keatas & Keatas & Keatas & Keatas & Keatas & Keatas & Keatas & Keatas & Keatas & Keatas & Keatas & Keatas & Keatas & Keatas & Keatas & Keatas \\
\hline Kerapatan cabang & Jarang & Jarang & Jarang & Rapat & Rapat & Rapat & Jarang & Rapat & Rapat & Rapat & Jarang & Rapat & Rapat & Jarang & Rapat & Jatang & Jatang & Rapat \\
\hline Warna batang & Coklat & $\begin{array}{l}\text { Coklat } \\
\text { Keputihan }\end{array}$ & Coklat & Coklat & Coklat & Coklat & Coklat & $\begin{array}{l}\text { Coklat } \\
\text { keputhhan }\end{array}$ & Coklat & & Coklat & Kecoklatan & Coklat & Coklat & $\begin{array}{l}\text { Coklat } \\
\text { keputhinan }\end{array}$ & Coklat & Coklat gelap & Coklat \\
\hline
\end{tabular}

Tabel 3. Karakteristik morfologi daun dari 18 varietas durian di kecamatan kota Bahagia

\begin{tabular}{|c|c|c|c|c|c|c|c|c|c|c|c|c|c|c|c|c|c|c|}
\hline \multirow[b]{2}{*}{ Karakter } & \multicolumn{18}{|c|}{ Varietas } \\
\hline & Jantung & Semut & Nanas & Kunyit & Bintang & Tamago & Labu & Bingen & Patai & Jelatang & Jerat & Ampo & Toba & Lilin & Kondo & Limeng & Langsat & $\begin{array}{l}\text { Gadang } \\
\text { tampuok }\end{array}$ \\
\hline $\begin{array}{l}\text { Warna } \\
\text { permukaan atas }\end{array}$ & Hijau tua & Hijau muda & Hijau tua & Hijau cerah & Hijau tua & Hijau tua & Hijau tua & Hijau cerah & $\begin{array}{l}\text { Hijau } \\
\text { kekuningan }\end{array}$ & Hijau tua & Hijau & Hijau tua & Hijau tua & Hijau kekuningan & Hijau tua & Hijautua & $\begin{array}{l}\text { Hijautua } \\
\end{array}$ & Hijautua \\
\hline $\begin{array}{l}\text { Warna } \\
\text { permukaan bawah }\end{array}$ & $\begin{array}{l}\text { Hijau } \\
\text { Keemasan }\end{array}$ & $\begin{array}{l}\text { Hijau } \\
\text { Keemasan }\end{array}$ & $\begin{array}{l}\text { Hijau } \\
\text { Keperakan }\end{array}$ & $\begin{array}{l}\text { Hijau } \\
\text { Keemasan }\end{array}$ & $\begin{array}{l}\text { Hijau } \\
\text { Keemasan }\end{array}$ & $\begin{array}{l}\text { Hijau } \\
\text { keemasan }\end{array}$ & $\begin{array}{l}\text { Hijau } \\
\text { keemasan }\end{array}$ & Hijau keemasan & $\begin{array}{l}\text { Hijau } \\
\text { keemasan }\end{array}$ & $\begin{array}{l}\text { Hijau } \\
\text { keemasan }\end{array}$ & $\begin{array}{l}\text { Hijau } \\
\text { keemasan }\end{array}$ & $\begin{array}{l}\text { Hijau } \\
\text { keemasan }\end{array}$ & $\begin{array}{l}\text { Hijau } \\
\text { keemasan }\end{array}$ & Hijau keemasan & $\begin{array}{l}\text { Hijau } \\
\text { keemasan }\end{array}$ & Hijaukeemasan & $\begin{array}{l}\text { Hijau } \\
\text { keemasan }\end{array}$ & Hijaukeemasan \\
\hline Kerapatan daun & Rapat & $\begin{array}{l}\text { Sangat } \\
\text { Rapat }\end{array}$ & Kurang Rapat & Rapat & Rapat & Rapat & Rapat & Kurang rapat & Rapat & Rapat & Kurang rapat & Rapat & Kurang rapat & Kurang rapat & Rapat & Rapat & Rapat & Kurangrapat \\
\hline $\begin{array}{l}\text { Duduk batang } \\
\text { Panjang tangkai }\end{array}$ & $\begin{array}{l}\text { Petiolata } \\
18,2\end{array}$ & $\begin{array}{l}\text { Petiolata } \\
17,6\end{array}$ & $\begin{array}{l}\text { Petiolata } \\
12.8\end{array}$ & $\begin{array}{l}\text { Petiolata } \\
12,2\end{array}$ & $\begin{array}{l}\text { Petiolata } \\
12,6\end{array}$ & $\begin{array}{l}\text { Petiolata } \\
14\end{array}$ & $\begin{array}{l}\text { Petiolata } \\
12,1\end{array}$ & $\begin{array}{l}\text { Petiolata } \\
10\end{array}$ & $\begin{array}{l}\text { Petiolata } \\
14\end{array}$ & $\begin{array}{l}\text { Petiolata } \\
13\end{array}$ & $\begin{array}{l}\text { Petiolata } \\
13\end{array}$ & $\begin{array}{l}\text { Petiolata } \\
12,4\end{array}$ & $\begin{array}{l}\text { Petiolata } \\
16\end{array}$ & $\begin{array}{l}\text { Petiolata } \\
14\end{array}$ & $\begin{array}{l}\text { Petiolata } \\
15\end{array}$ & $\begin{array}{l}\text { Petiolata } \\
12,5\end{array}$ & $\begin{array}{l}\text { Petiolata } \\
12\end{array}$ & $\begin{array}{l}\text { Petiolata } \\
18\end{array}$ \\
\hline $\begin{array}{l}\text { Kondisi tangkai } \\
\text { daun }\end{array}$ & Datar & Membulat & $\begin{array}{l}\text { Setengah } \\
\text { Lingkaran }\end{array}$ & Membukat & Datar & Membulat & Datar & Membulat & $\begin{array}{l}\text { Setengah } \\
\text { lingkaran }\end{array}$ & Membulat & Membulat & Datar & Datar & $\begin{array}{l}\text { Setengah } \\
\text { lingkaran }\end{array}$ & Datar & $\begin{array}{l}\text { Setengah } \\
\text { lingkaran }\end{array}$ & Datar & Membulat \\
\hline $\begin{array}{l}\text { Lebar helaian } \\
\text { daun }(\mathrm{cm})\end{array}$ & 4,1 & 3,6 & 4,5 & 4,3 & 4,9 & 3,5 & 4,5 & 3,8 & 4,2 & 4,3 & 3,8 & 4,2 & 4,8 & 3,2 & 3 & 4,5 & 3,7 & 4,7 \\
\hline $\begin{array}{l}\text { Bentuk helaian } \\
\text { daun }\end{array}$ & Persegi & $\begin{array}{l}\text { Bulat } \\
\text { Panjang }\end{array}$ & Membulat & Bulat Panjang & Bulat Telur & Membuat & $\begin{array}{l}\text { Bulat } \\
\text { panjang }\end{array}$ & Bulat & Membulat & Membulat & Membulat & $\begin{array}{l}\text { Membulat } \\
\text { panjang }\end{array}$ & Membulat & Membulat & Bulat & Bulat panjang & Bulat & $\begin{array}{l}\text { Membulat } \\
\text { panjang }\end{array}$ \\
\hline $\begin{array}{l}\text { Bentuk ujung } \\
\text { daun }\end{array}$ & Runcing & Tumpul & $\begin{array}{l}\text { Runcing } \\
\text { Bergelombang }\end{array}$ & Meruncing & Tumpul & Meruncing & Meruncing & Tumpul & Tumpul & Tumpul & Lonjong & Lonjong & Lonjong & Sedikit oval & Lonjong & $\begin{array}{l}\text { Lonjong } \\
\text { bergelombang }\end{array}$ & Tumpul & $\begin{array}{l}\text { Lonjong } \\
\text { bergelombang }\end{array}$ \\
\hline $\begin{array}{l}\text { Bentuk dasar } \\
\text { daun }\end{array}$ & Lonjong & Sedikit Oval & $\begin{array}{l}\text { Lonjong } \\
\text { Bergelombang }\end{array}$ & Lonjong & SedikitOval & Lonjong & Oval & Sedikit oval & Oval & Lonjong & Lonjong & Lonjong & Lonjong & Sedikit oval & Lonjong & $\begin{array}{l}\text { Lonjong } \\
\text { bergelombang }\end{array}$ & Lonjong & $\begin{array}{l}\text { Lonjong } \\
\text { bergelombang }\end{array}$ \\
\hline Margin daun & Rata & Rata & Bergelombang & Rata & Rata & Rata & Rata & $\begin{array}{l}\begin{array}{l}\text { Sedikit } \\
\text { bergelombang }\end{array} \\
\end{array}$ & Rata & Rata & Rata & Rata & Rata & Bergelombang & Rata & Bergelombang & Rata & Bergelombang \\
\hline
\end{tabular}


Mardudi, et al. (2021). Jurnal Biologi Tropis, 21 (1): $42-51$

Tabel 4. Karakteristik morfologi buah dari 18 varietas durian di kecamatan kota Bahagia

\begin{tabular}{|c|c|c|c|c|c|c|c|c|c|c|c|c|c|c|c|c|c|c|}
\hline \multirow[b]{2}{*}{ Karakter } & \multicolumn{18}{|c|}{ Varietas } \\
\hline & Jantung & Semut & Nanas & Kunyit & Bintang & Tamago & Labu & Bingen & Patai & Jelatang & Jerat & Ampo & Toba & Lilin & Kondo & Limeng & Langsat & $\begin{array}{l}\text { Gadang } \\
\text { tampuok }\end{array}$ \\
\hline $\begin{array}{l}\text { Bentuk } \\
\text { Buah }\end{array}$ & Jantung & Membulat & $\begin{array}{l}\text { Lonjong } \\
\text { memanjang }\end{array}$ & Membulat & Persegi & Lonjong & Bulat pipih & Membulat & Membulat & Membulat & Bulat & Lonjong & Membulat & Bulat & Membulat & Lonjong & Membulat & Lonjong \\
\hline Keunikan & $\begin{array}{l}\text { Buah } \\
\text { berbentuk } \\
\text { jantung }\end{array}$ & $\begin{array}{l}\text { Buah dikerumuni } \\
\text { semut }\end{array}$ & $\begin{array}{l}\text { Buah } \\
\text { berbentuk } \\
\text { mirip nanas }\end{array}$ & $\begin{array}{l}\text { Daging isi } \\
\text { buah } \\
\text { berwarna } \\
\text { orange }\end{array}$ & $\begin{array}{l}\text { Buh } \\
\text { berbentuk } \\
\text { segilima }\end{array}$ & $\begin{array}{l}\text { Buah } \\
\text { berwarna } \\
\text { kekuningan }\end{array}$ & $\begin{array}{l}\text { Buah mirip } \\
\text { buah labu }\end{array}$ & $\begin{array}{l}\text { Buah } \\
\text { bercorak } \\
\text { hijau } \\
\text { keperakan }\end{array}$ & $\begin{array}{l}\text { Buah pipih } \\
\text { mirip seperti } \\
\text { petai }\end{array}$ & $\begin{array}{l}\text { Ada } \\
\text { pohon } \\
\text { jelatang di } \\
\text { dekatnya }\end{array}$ & $\begin{array}{l}\text { Buah } \\
\text { banyak } \\
\text { memiliki } \\
\text { tali } \\
\text { beringin di } \\
\text { pohon }\end{array}$ & $\begin{array}{l}\text { Buah } \\
\text { memiliki } \\
\text { biji } \\
\text { kosong/ } \\
\text { tidak } \\
\text { berbiji }\end{array}$ & $\begin{array}{l}\text { Buah } \\
\text { memiliki } \\
\text { daging } \\
\text { yang tebal }\end{array}$ & $\begin{array}{l}\text { Memiliki } \\
\text { bentuk } \\
\text { bulat } \\
\text { sempurna }\end{array}$ & $\begin{array}{l}\text { Memiliki } \\
\text { kondo atau } \\
\text { duri di } \\
\text { dalam buah }\end{array}$ & $\begin{array}{l}\text { Bentuk } \\
\text { buah } \\
\text { lonjong }\end{array}$ & $\begin{array}{l}\text { Tumbuh } \\
\text { dekat } \\
\text { pohon } \\
\text { Langsat }\end{array}$ & $\begin{array}{l}\text { Buah } \\
\text { memiliki } \\
\text { tangkai } \\
\text { yang besar } \\
\text { dari lainnya }\end{array}$ \\
\hline $\begin{array}{l}\text { Bentuk } \\
\text { ujung } \\
\text { buah }\end{array}$ & Runcing & Membulat & Runcing & Membulat & Runcing & Runcing & Membulat & Membulat & Membulat & Membulat & Bulat & Meruncing & Membulat & Bulat & Bulat & Meruncing & Membulat & Meruncing \\
\hline $\begin{array}{l}\text { Bentuk } \\
\text { dasar buah }\end{array}$ & $\begin{array}{l}\text { Jant } \\
\text { ung }\end{array}$ & $\begin{array}{l}\text { Membula } \\
\mathrm{t}\end{array}$ & Lonjong & Bulat & $\begin{array}{l}\text { Bersegi } \\
\text { Lima }\end{array}$ & Lonjong & Membulat & Membulat & Membulat & Membulat & Bulat & Lonjong & Membulat & Bulat & Bulat & Lonjong & Membulat & Lonjong \\
\hline $\begin{array}{l}\text { Panjang } \\
\text { tangaki } \\
\text { buah }(\mathrm{cm})\end{array}$ & 3,5 & 2 & 4 & 3 & 4 & 4 & 3 & 3 & 4 & 4 & 3 & 4,2 & 4 & 3,5 & 3 & 3 & 4 & 3 \\
\hline $\begin{array}{l}\text { Kekuatan } \\
\text { perlekatan } \\
\text { tangkai } \\
\text { buah }\end{array}$ & Sangat Kuat & Cukup Kuat & Cukup Kuat & SangatKuat & Sangat Kuat & Sangat kuat & Cukup kuat & $\begin{array}{l}\text { Sangat } \\
\text { kuat }\end{array}$ & Kuat & $\begin{array}{l}\text { Sangat } \\
\text { kuat }\end{array}$ & Cukup kuat & $\begin{array}{l}\text { Sangat } \\
\text { kuat }\end{array}$ & $\begin{array}{l}\text { Sangat } \\
\text { kuat }\end{array}$ & Cukup kuat & Kuat & Kuat & Sangat kuat & Sangat kuat \\
\hline $\begin{array}{l}\text { Bentuk } \\
\text { duri buah }\end{array}$ & $\begin{array}{l}\text { Segitigamele } \\
\text { ngkung }\end{array}$ & $\begin{array}{l}\text { Segitiga } \\
\text { melengkung }\end{array}$ & Piramida & Segitiga & $\begin{array}{l}\text { Segitiga } \\
\text { melengkung }\end{array}$ & Firamida & $\begin{array}{l}\text { Segitiga } \\
\text { runcing }\end{array}$ & $\begin{array}{l}\text { Segitiga } \\
\text { runcing }\end{array}$ & Firamida & $\begin{array}{l}\text { Segitiga } \\
\text { meruncing }\end{array}$ & Piramida & $\begin{array}{l}\text { Segitiga } \\
\text { meruncing }\end{array}$ & Segitiga & Segitiga & Segitiga & Piramida & Piramida & Segitiga \\
\hline Duri buah & Besar & Kecil & Besar & Kecil & Sedang & Sedang & Besar & Sedang & Sedang & Besar & Kecil & Besar & Besar & Kecil & Sedang & Sedang & Kecil & Kecil \\
\hline $\begin{array}{l}\text { Permukaa } \\
\text { n duri } \\
\text { buah }\end{array}$ & Halus & Kasar & Halus & Halus & Kasar & Halus & Kasar & Kasar & Halus & Halus & Kasar & Kasar & Kasar & Halus & Kasar & Halus & Halus & Kasar \\
\hline $\begin{array}{l}\text { Kerapatan } \\
\text { duri buah }\end{array}$ & CukupRapat & Sangat Rapat & Rapat & Sangat Rapat & Sangat Rapat & Rapat & Rapat & $\begin{array}{l}\text { Sangat } \\
\text { rapat }\end{array}$ & Cukup rapat & Rapat & $\begin{array}{l}\text { Sangat } \\
\text { rapat }\end{array}$ & Rapat & Jarang & $\begin{array}{l}\text { Sangat } \\
\text { rapat }\end{array}$ & $\begin{array}{l}\text { Sangat } \\
\text { rapat }\end{array}$ & Rapat & $\begin{array}{l}\text { Sangat } \\
\text { rapat }\end{array}$ & $\begin{array}{l}\text { Sangat } \\
\text { rapat }\end{array}$ \\
\hline $\begin{array}{l}\text { Panjang } \\
\text { duri buah } \\
(\mathrm{cm})\end{array}$ & 1 & 1.5 & 1 & 1 & 1,5 & 1 & 1,5 & 1 & 1 & 1 & 1,6 & 1 & 1 & 1.4 & 1,5 & 1 & 1,5 & 1,4 \\
\hline $\begin{array}{l}\text { Diameter } \\
\text { buah }(\mathrm{cm})\end{array}$ & 30 & 25 & 20 & 20 & 32 & 35 & 40 & 25 & 24 & 30 & 20 & 43 & 42 & 24 & 30 & 25 & 23 & 25 \\
\hline $\begin{array}{l}\text { Berat buah } \\
(\mathrm{kg})\end{array}$ & $2-4$ & 1,5 & 1 & $2-3$ & $2-4$ & $3-5$ & $3-5$ & $2-3$ & $2-3$ & 4 & $2-3$ & $2-3$ & $3-5$ & $2-3$ & $2-4$ & $3-4$ & $2-3$ & $2-4$ \\
\hline $\begin{array}{l}\text { Ketebalan } \\
\text { kulit buah } \\
(\mathrm{cm})\end{array}$ & 1 & 1 & 1,5 & 2 & 1,5 & 2 & 3 & 1 & 2 & 3 & 1 & 2 & 3,5 & 2 & 3 & 1,5 & 1 & 1 \\
\hline $\begin{array}{l}\text { Warna } \\
\text { kulit buah }\end{array}$ & Hijau & $\begin{array}{l}\text { Kuning } \\
\text { Kecoklatan }\end{array}$ & $\begin{array}{l}\text { Hijau } \\
\text { Kekuningan }\end{array}$ & Kuning & $\begin{array}{l}\text { Hijau } \\
\text { Kekuningan }\end{array}$ & $\begin{array}{l}\text { Hijau } \\
\text { kekuningan }\end{array}$ & $\begin{array}{l}\text { Hijau } \\
\text { keperakan }\end{array}$ & $\begin{array}{l}\text { Hijau } \\
\text { keperakan }\end{array}$ & $\begin{array}{l}\text { Hijau } \\
\text { kekuningan }\end{array}$ & Hijau & $\begin{array}{l}\text { Hijau } \\
\text { kecoklatan }\end{array}$ & $\begin{array}{l}\text { Hijau } \\
\text { kecoklatan }\end{array}$ & Hijau tua & $\begin{array}{l}\text { Hijau } \\
\text { kekuningan }\end{array}$ & Hijau tua & Kuning & $\begin{array}{l}\text { Hijau } \\
\text { kekuningan }\end{array}$ & Hijau tua \\
\hline $\begin{array}{l}\text { Ketebalan } \\
\text { ari buah }\end{array}$ & Sangattebal & CukupTebal & Tebal & CukupTebal & Tebal & Tebal & $\begin{array}{l}\text { Sangat } \\
\text { tebal }\end{array}$ & $\begin{array}{l}\text { Cukup } \\
\text { tebal }\end{array}$ & Tebal & Tebal & Tebal & $\begin{array}{l}\text { Sangat } \\
\text { tebal }\end{array}$ & $\begin{array}{l}\text { Sangat } \\
\text { tebal }\end{array}$ & Tebal & Tebal & Tebal & $\begin{array}{l}\text { Cukup } \\
\text { tebal }\end{array}$ & Tebal \\
\hline
\end{tabular}


Mardudi, et al. (2021). Jurnal Biologi Tropis, 21 (1): $42-51$

\begin{tabular}{|c|c|c|c|c|c|c|c|c|c|c|c|c|c|c|c|c|c|c|}
\hline $\begin{array}{l}\text { Tekstur ari } \\
\text { buah }\end{array}$ & Lembut & Lembut & CukupLembut & Lembut & Lembut & Lembut & $\begin{array}{l}\text { Cukup } \\
\text { lembut }\end{array}$ & Lembut & Lembut & $\begin{array}{l}\text { Cukup } \\
\text { Lembut }\end{array}$ & Lembut & $\begin{array}{l}\text { Sangat } \\
\text { lembut }\end{array}$ & Lembut & Lembut & Lembut & Lembut & Lembut & $\begin{array}{l}\text { Sangat } \\
\text { lembut }\end{array}$ \\
\hline $\begin{array}{l}\text { Rasa buah } \\
\text { segar }\end{array}$ & SangatManis & ManisLegit & Manis & Manis Legit & Manis & $\begin{array}{l}\text { Sangat } \\
\text { manis }\end{array}$ & Manis legit & $\begin{array}{l}\text { Cukup } \\
\text { manis }\end{array}$ & Manis & $\begin{array}{l}\text { Cukup } \\
\text { manis }\end{array}$ & Manis & Manis legit & Manis legit & $\begin{array}{l}\text { Cukup } \\
\text { manis }\end{array}$ & Manis legit & Manis asam & Manis & $\begin{array}{l}\text { Sangat } \\
\text { manis }\end{array}$ \\
\hline $\begin{array}{l}\text { Aroma } \\
\text { buah segar }\end{array}$ & Harum & HarumTajam & SangatHarum & HarumTajam & $\begin{array}{l}\text { SangatHaru } \\
\mathrm{m}\end{array}$ & $\begin{array}{l}\text { Harum } \\
\text { tajam }\end{array}$ & $\begin{array}{l}\text { Harum } \\
\text { menyengat }\end{array}$ & Harum & Harum tajam & Harum & Harum & $\begin{array}{l}\text { Harum } \\
\text { menyengat }\end{array}$ & $\begin{array}{l}\text { Harum } \\
\text { menyengat }\end{array}$ & $\begin{array}{l}\text { Harum } \\
\text { tajam }\end{array}$ & $\begin{array}{l}\text { Harum } \\
\text { menyengat }\end{array}$ & Harum & $\begin{array}{l}\text { Harum } \\
\text { tajam }\end{array}$ & $\begin{array}{l}\text { Harum } \\
\text { tajam }\end{array}$ \\
\hline $\begin{array}{l}\text { Warna } \\
\text { buah segar }\end{array}$ & Putih & Kuning & Putih & $\begin{array}{l}\text { Kuning ke } \\
\text { orenan }\end{array}$ & Kuning & $\begin{array}{l}\text { Kuning ke } \\
\text { orenan }\end{array}$ & Kuning & Putih & Kuning & Putih & Putih & Kuning & Kuning & $\begin{array}{l}\text { Kuning } \\
\text { keputihan }\end{array}$ & Kuning & Kuning & Putih & $\begin{array}{l}\text { Kuning } \\
\text { keputihan }\end{array}$ \\
\hline $\begin{array}{l}\text { Jumlah } \\
\text { biji } \\
\text { perlokus }\end{array}$ & $3-5$ & $2-3$ & 3 & 3 & $3-5$ & $3-5$ & $3-5$ & $4-6$ & $3-5$ & $3-5$ & $3-5$ & $4-6$ & $4-6$ & $4-6$ & 4 & $3-5$ & $3-5$ & $3-4$ \\
\hline $\begin{array}{l}\text { Panjang } \\
\text { biji (cm) }\end{array}$ & $2-4$ & 3 & 2 & 4 & 3 & 3 & 3 & 2 & 3 & 3 & 2 & 2 & 2 & 2 & 2 & 3 & 2 & 3 \\
\hline $\begin{array}{l}\text { Lebar biji } \\
\text { (cm) }\end{array}$ & 3 & 2 & 3 & 3 & 3 & $2-3$ & 3 & $2-3$ & 3 & $2-3$ & 2 & 3-4 & 3 & 2 & 3 & 3-4 & 2 & 2 \\
\hline $\begin{array}{l}\text { Bentuk } \\
\text { biji }\end{array}$ & Lonjong & Oval & Lonjong & Lonjong & Lonjong & Lonjong & Lonjong & Membulat & Membulat & Lonjong & Lonjong & Lonjong & Lonjong & Bulat & Bulat & Membulat & Bulat & Lonjong \\
\hline $\begin{array}{l}\text { Warna } \\
\text { kulit biji }\end{array}$ & PutihKusam & $\begin{array}{c}\text { Kuning } \\
\text { Kecoklatan }\end{array}$ & Kekuningan & $\begin{array}{l}\text { KuningKe } \\
\text { coklatan }\end{array}$ & Kekuningan & $\begin{array}{l}\text { Kuning } \\
\text { kecoklatan }\end{array}$ & $\begin{array}{l}\text { Kuning } \\
\text { keputihan }\end{array}$ & $\begin{array}{l}\text { Kuning } \\
\text { kusam }\end{array}$ & $\begin{array}{l}\text { Kuning } \\
\text { kecoklatan }\end{array}$ & $\begin{array}{l}\text { Kuning } \\
\text { keputihan }\end{array}$ & Putih & $\begin{array}{l}\text { Kuning } \\
\text { kecoklatan }\end{array}$ & $\begin{array}{l}\text { Kuning } \\
\text { kecoklatan }\end{array}$ & Putih & $\begin{array}{l}\text { Kuning } \\
\text { kecoklatan }\end{array}$ & $\begin{array}{l}\text { Kuning } \\
\text { kusam }\end{array}$ & $\begin{array}{l}\text { Kuning } \\
\text { keputihan }\end{array}$ & $\begin{array}{l}\text { Kuning } \\
\text { kecoklatan }\end{array}$ \\
\hline
\end{tabular}


Mardudi, et al. (2021). Jurnal Biologi Tropis, 21 (1): 42 - 51

DOI: http://dx.doi.org/10.29303/jbt.v21i1.2361

Tabel 5. Nilai indeks kesamaan pasangan STO dari 18 varietas durian di kecamatan Kota Bahagia

\begin{tabular}{|c|c|c|c|c|c|c|c|c|c|c|c|c|c|c|c|c|c|c|}
\hline & $\mathbf{J a}$ & Se & $\mathbf{N a}$ & $\mathbf{K u}$ & $\mathbf{B i}$ & Ta & La & Bn & $\mathbf{P a}$ & $\mathbf{J e}$ & $\mathbf{J r}$ & Am & To & $\mathbf{L i}$ & Ko & $\mathbf{L m}$ & Ln & Gt \\
\hline Ja & & 21,73 & 30,43 & 26,08 & 28,26 & 39,13 & 39,13 & 26,08 & 30,43 & 39,13 & 41,30 & 34,78 & 30,43 & 17,39 & 30,43 & 26,08 & 36,95 & 23,91 \\
\hline Se & & & 15,21 & 30,43 & 28,26 & 39,13 & 34,78 & 34,78 & 30,43 & 23,91 & 26,08 & 19,56 & 26,08 & 28,26 & 26,08 & 26,08 & 36,95 & 32,60 \\
\hline $\mathrm{Na}$ & & & & 26,08 & 32,60 & 36,95 & 17,39 & 32,60 & 34,78 & 36,95 & 34,78 & 26,68 & 30,43 & 34,78 & 15,21 & 36,13 & 28,26 & 23,91 \\
\hline $\mathbf{K u}$ & & & & & 30,43 & 43,47 & 30,43 & 36,95 & 41,30 & 43,47 & 39,13 & 36,95 & 39,15 & 32,60 & 39,13 & 26,08 & 36,95 & 32,60 \\
\hline $\mathbf{B i}$ & & & & & & 39,13 & 36,95 & 28,26 & 41,30 & 41,30 & 34,78 & 28,26 & 34,78 & 26,08 & 43,47 & 32,60 & 36,95 & 30,43 \\
\hline Ta & & & & & & & 28,26 & 23.91 & 52,17 & 50,00 & 28,26 & 47,82 & 43,47 & 26,06 & 28,26 & 41,30 & 43,47 & 39,13 \\
\hline La & & & & & & & & 23,91 & 36,95 & 47,82 & 28,26 & 43,47 & 41,30 & 21,73 & 34,78 & 32,60 & 30,43 & 23,91 \\
\hline Bn & & & & & & & & & 32,60 & 39,13 & 32,60 & 41,30 & 34,78 & 26,08 & 32,60 & 32,60 & 39,13 & 28,26 \\
\hline $\mathbf{P a}$ & & & & & & & & & & 50,00 & 50,00 & 30,43 & 39,13 & 26,08 & 34,78 & 63,04 & 43,47 & 21,73 \\
\hline $\mathbf{J e}$ & & & & & & & & & & & 36,95 & 34,78 & 41,30 & 21,73 & 30,43 & 34,78 & 41,30 & 26,08 \\
\hline $\mathbf{J r}$ & & & & & & & & & & & & 23,91 & 30,43 & 45,65 & 39,13 & 28,13 & 39,13 & 34,78 \\
\hline Am & & & & & & & & & & & & & 52,17 & 19,56 & 34,78 & 30,43 & 30,43 & 34,78 \\
\hline To & & & & & & & & & & & & & & 26,47 & 43,43 & 21,73 & 36,95 & 32,60 \\
\hline $\mathbf{L i}$ & & & & & & & & & & & & & & & 26,08 & 28,26 & 32,60 & 32,60 \\
\hline Ko & & & & & & & & & & & & & & & & 28,26 & 36,95 & 30,43 \\
\hline Lm & & & & & & & & & & & & & & & & & 28,26 & 34,78 \\
\hline Ln & & & & & & & & & & & & & & & & & & 28,26 \\
\hline Gt & & & & & & & & & & & & & & & & & & \\
\hline
\end{tabular}

Keterangan: Ja=Jantung; Se=Semut; Na=Nanas; Ku=Kunyit; Bi=Bintang; Ta=Tamago; La=Labu; Bn=Bingin; Pa=Patai; Je=Jerat; Jr=Jerat; Am=Ampo; To=Toba; Li=Lilin; Ko=Kondo; Lm=Limeng; Ln=Langsek; Gt;GadangTampuk.

\section{Kesimpulan}

Sebanyak 18 varietas durian yang ditemukan di Kec. Kota Bahagia dengan karakter morfologi durian yang sangat beragam baik dari morfologi batang, daun, maupun buah. Nilai indeks kesamaan tertinggi terdapat pada varietas Limeng $(\mathrm{Lm})$ dan varietas Patai (Pa) dengan nilai koefisien asosiasi sebesar 63,04, sedangkan nilai terendah terdapat pada varietas Nanas (Na) dengan varietas semut (Se) dan varietas Kondo (Ko) dan varietas Nanas (Na) dengan nilai koefisien asosiasi masing-masing sebesar 15,21. Varietas durian Jantung, durian Kunyit, dan durian Labu merupakan varietas durian yang berpotensi untuk dikembangkan di Kec. Kota Bahagia.

\section{Ucapan Terima kasih}

Penulis mengucapkan terimakasih kepada seluruh masyarakat di lokasi penelitian yang telah membantu pelaksanaan penelitian ini. Kami juga mengucapkan terimakasih kepada pimpinan Universitas Samudra yang telah memberikan dukungan dalam kegiatan penelitian ini.

\section{Referensi}

Bioversity International (2007). Descriptors for Durian (Durio zibethinus Murr.) Rome, Italy: Bioversity Internasional.

BPS (2019). Kecamatan kota Bahagaia dalam Angka 2019. Aceh Selatan: Badan Statistik Aceh Selatan.

BPS (2018). Statistik Pertanian Hortikultura. SPHSBS/BPS-Statistic Indonesia, Agriculture Statistic for Horticulture SPH-SB.

Elfrida, Mubarak, A., \& Suwardi, AB. (2020). The fruit plant species diversity in the home gardens and their contribution to the livelihood of communities in rural area. Biodiversitas 21 (8), 3670-3675.

https://smujo.id/biodiv/article/view/6307

Feng, J., Wang, Y., Yi, X., Yang, W., \& He, X. (2016). Phenolics from Durian Exert Pronounced NO Inhibitory and Antioxidant Activities. Journal of Agricultural and Food Chemistry 64(21), 4273-4279.

https://pubs.acs.org/doi/abs/10.1021/acs.jafc.6b $\underline{01580}$

Handayani, R, \& Ismadi, S. (2017). Analisis Keragaman Kualitas Buah Durian Unggulan 
Mardudi, et al. (2021). Jurnal Biologi Tropis, 21 (1): 42 - 51

DOI: http://dx.doi.org/10.29303/jbt.v21i1.2361

(Durio zibethinus) Aceh Utara. Jurnal Hortikultura Indonesia 8(3):147-154. http://journal.ipb.ac.id/index.php/jhi/article/vie $\underline{w} / 20137$

Hardiyanto, Mujiarto, E., \& Sulasmi, E.S. (2006). Kekerabatan beberapa spesies jeruk berdasarkan taksonometri. J. Hort. 17(3): 203216.

Mansur, M. (2007). Penelitian Ekologi Jenis Durian (Durio spp.) di Desa Intuh Lingau, Kalimantan Timur. Jurnal Teknologi Lingkungan 8: 211216.

http://ejurnal.bppt.go.id/index.php/JTL/article/ view/427

Najira, N., Selviyanti, E., Tobing, Y. B., Kasmawati, K., Sianturi, R., \& Suwardi, A. B. (2020). Diversitas Kultivar tanaman Durian (Durio zubethinus Murr.) Ditinjau dari Karakter Morfologi. Jurnal Biologi Tropis, 20(2), 185193.

http://jurnalfkip.unram.ac.id/index.php/JBT/art icle/view/1871

Navia, Z. I., \& Chikmawati, T. (2015). Durio tanjungpurensis (Malvaceae), a new species and its one new variety from West Kalimantan, Indonesia. Bangladesh Journal of Botany, 44(3), 429-436. https://www.banglajol.info/index.php/BJB/artic le/view/38550

Navia, Z.I., Suwardi, A.B., \& Saputri, A. (2017). Penelusuran ragam jenis tanaman buah pekarangan sebagai sumber nutrisi bagi masyarakat di Kota Langsa, Aceh. Dalam: Agustien, A., Syaifullah, Pitopang, RP, Nurainas, Ilyas, S. \& Kurniawan, R.(editor) Prosiding Seminar Nasional Biodiversitas dan Ekologi Tropika Indonesia Ke-4 dan Kongres Penggalang Taksonomi Tumbuhan Indonesia Ke-12. Padang. Hal 774-782.

Navia, Z.I., Suwardi, A.B., \& Saputri, A. (2019). Karakterisasi Tanaman Buah Lokal di Kawasan Ekosistem Leuser Kabupaten Aceh Tamiang, Aceh. Bul. Plasma Nutfah 25(2): 133-142.
Navia, Z.I., Suwardi, A.B., Harmawan, T., Syamsuardi, \& Mukhtar, E. (2020a). The diversity and contribution of indigenous edible fruit plants to the rural community in the Gayo Highlands, Indonesia. Journal of Agriculture and Rural Development in the Tropics and Subtropics. 121(1): 89-98.

Navia, Z.I., Suwardi, A.B., Nuraini, \& Seprianto (2020b). Ethnobotany of wild edible fruit species and their contribution to food security in the North Aceh region, Indonesia. The International Conference on ASEAN 2019: 203210 .

Navia, Z.I., Suwardi, A.B., \& Nuraini (2021). The importance of tropical edible fruit plants for tribal communities in East Aceh region, Indonesia. Earth Environ. Sci. 637: 012003. https://iopscience.iop.org/article/10.1088/17551315/637/1/012003/meta

Noverian, W., Suwardi, A.B., \& Mubarak, A. (2020). Inventarisasi Jenis Buah-Buahan Lokal Sebagai Sumber Pangan Bagi Masyarakat Lokop Aceh Timur. Jurnal Jeumpa 7(1): 319-327. https://www.ejurnalunsam.id/index.php/jempa/ article/view/2956

Nurlaila, Ilyas, A., \& Sahardi. (2019). Inventarisasi dan Karakterisasi Keragaman Morfologi Durian Lokal (Durio zibethinus Murr.) di Provinsi Sulawesi Selatan. Bul. Plasma Nutfah 25(1):5362.

http://www.ejurnal.litbang.pertanian.go.id/inde x.php/bpn/article/view/10529

Purba, M, Marsela, A, Mustika, R, Subakti, R, Khairani, S, dan Suwardi, AB. (2020). Potensi Pengembangan Agroforestri Berbasis Tumbuhan Buah Lokal. Jurnal Ilmiah $\begin{array}{llll}\text { Pertanian } & 17 & \text { (1), 27-34. }\end{array}$ http://journal.unilak.ac.id/index.php/jip/article/ view/4113

Purnomosidhi, P., Suparman, Roshetko, J.M., \& Mulawarman. (2002). Perbanyakan dan Budidaya Tanaman Buah-buahan Dengan Penekanan Pada Durian, Mangga, Jeruk, Melinjo dan Sawo.International Center for 
Mardudi, et al. (2021). Jurnal Biologi Tropis, 21 (1): 42 - 51

DOI: http://dx.doi.org/10.29303/jbt.v21i1.2361

Research in Agroferestry dan Winrock International.

Rusmiati, Mulyanto, E., Ashari, S., Widodo, M. A., \& Bansir, L. (2013). Eksplorasi, inventarisasi dan karakterisasi durian merah Banyuwangi. Prosiding Semirata FMIPA Universitas Lampung.

Salasa, N., Arum, K., Ashari, S., \& Herlina, N. (2013). Identifikasi tanaman durian (Durio zibethinus Murray) mirip durian varietas Bido di Kecamatan Wonosalam Kabupaten Jombang dengan metode isozim dan morfologi. Jurnal Produksi Tanaman. 1(5): 427-433. http://protan.studentjournal.ub.ac.id/index.php/ protan/article/view/54

Santoso, P.J. (2014). Kalender Budidaya Durian. Balai Penelitian Tanaman BuahTropika, Solok.

Sembiring, M. B., Rahmi, D., Maulina, M., Tari, V., Rahmayanti, R., \& Suwardi, A. B. (2020). Identifikasi Karakter Morfologi dan Sensoris Kultivar Mangga (Mangifera Indica L.) di Kecamatan Langsa Lama, Aceh, Indonesia. Jurnal Biologi Tropis, 20(2), 179184.

http://www.jurnalfkip.unram.ac.id/index.php/J BT/article/view/1876

Sundari. (2014). Keanekaragaman durian lokal di Jailolo kabupaten Halmahera Barat berdasarkan karakter dan morfologi. Jurnal Pena Sains 1(1): 9-14.

Suwardi, A.B., Navia, Z.I., Harmawan, T., Syamsuardi, \& Mukhtar, E. (2019a). The diversity of wild edible fruit plants and traditional knowledge in West Aceh region, Indonesia. Journal of Medicinal Plants Studies 7(4):

285-290.

https://www.researchgate.net/profile/Adi_Bejo

Suwardi/publication/335715920

Suwardi, A.B., Navia, Z.I., Harmawan, T., Syamsuardi, \& Mukhtar, E. (2019b). Sensory Evaluation of Mangoes Grown in Aceh Tamiang District, Aceh, Indonesia. Advances in Ecological and Environmental Research 4 (3): 79-85.

Suwardi, A.B., Navia, Z.I., Harmawan, T., Syamsuardi, \& Mukhtar, E. (2020a). Ethnobotany, nutritional composition and sensory evaluation of Garcinia from Aceh, Indonesia. Materials Science and Engineering 725: 012064.

Suwardi, A.B., Navia, Z.I., Harmawan, T., Syamsuardi, \& Mukhtar, E. (2020b). Ethnobotany and conservation of indigenous edible fruit plants in South Aceh, Indonesia. Biodiversitas $\quad 21(5)$ : 1850-1860. https://www.smujo.id/biodiv/article/view/4810

Suwardi, A.B., Navia, Z.I., Harmawan, T., Syamsuardi, \& Mukhtar, E. (2020c). Wild edible fruits generate substantial income for local people of the Gunung Leuser National Park, Aceh Tamiang Region. Ethnobotany Research \& Applications 20:11

Uji, T. (2005). Keanekaragam jenis dan sumber plasma nutfah durian (Durio spp.) di Indonesia. Buletin Plasma Nutfah 11(1): 28-33. 